\title{
KOMPETENSI ENOCH ATMADIBRATA \\ PADA KESENIAN JAWA BARAT
}

\author{
Icuh Komala \\ Universitas Nusaputra \\ Jl No.21, Cibolang Kaler, Cisaat, Sukabumi, Jawa Barat 43155 \\ Email: icuh.komala@nusaputra.ac.id
}

\begin{abstract}
Competence is an integrated complex of skill and knowledge upon which an artist relies within a particular context. Enoch Atmadibrata was an artist in West Java who reached the level degree of competence. His skills and knowledge had contributed to the Sundanese arts. This study is written on the assumption that there is a complex of knowledge and practice subsumable under Enoch. This study takes us to the very heart of making arts and performing art, also creating concepts and theoretical nature of the arts which he is involved in. This investigation is very primarily for our reflection and lessons.
\end{abstract}

Key word: Atmadibrata, competence, contribution, Enoch, Kawit

\section{PENDAHULUAN}

Seniman dikatakan mencapai derajat kompetensi apabila memberikan kontribusi nyata pada kesenian yang ditekuni, disertai penguasaan skill dan knowledge yang diinterelasi dengan mentalitas saat perfoma di atas panggung (Brinner, 1995:1). Seniman tersebut menjadi sosok yang diakui kepakarannnya, karena seimbang dalam tataran praktik dan knowledge. Pendikotomian antara seniman yang telah dan belum mencapai derajat kompetensi menjadi penting diklasifikasikan, karena sekali pun yang berkiprah menjadi seniman sangat banyak, hanya beberapa yang berpengaruh diakui kompetensi kepakarannya. Sisanya dianggap seniman capable atau disebut 'tukang', sekedar ber- partisipasi tanpa berusaha memanfaatkan dan meningkatkan bakat yang dimiliki, apalagi memberikan kontribusi - seperti dikatakan Brinner atau memahami 'kedalaman' yang dapat digali dari seni yang ditekuninya. ${ }^{1}$ Figur seniman dengan kriteria derajat kompetensi, ditemukan pada sosok bernama Enoch Atmadibrata, yang secara nyata memberikan sumbangsih terhadap keberlangsungan, perkembangan, dan pembaharuan kekaryaan pada kesenian di Jawa Barat.

Enoch adalah seniman yang berperan secara multi, yakni sebagai seniman penyaji dan pencipta, dengan segala konsekwensi yang diterima. ${ }^{2}$ Sebagai seniman penyaji, ia dituntut menjaga dan melestarikan kehidupan seni tra- 
disi, mau tidak mau terikat konsensus etika dan estetika pada sistem nilai dan pranata sosial yang melembaga di lingkungan budayanya (baca: Sunda); sedangkan sebagai seniman pencipta dituntut melahirkan ide-ide pembaruan (konsep) yang diwujudkan dalam bentuk kekaryaan, walau dicapai dengan mendobrak kemapanan estetika seni tradisi yang ditekuninya. Konsekwensinya adalah kegagalan memainkan dua peranan yang paradoks itu secara bersamaan. Kegagalan yang relatif tidak dialami, karena Enoch melahirkan kekaryaan yang merepresentasikan dua kekuatan skill dan knowledge seimbang, baik ketika berperan sebagai penyaji maupun pencipta. Kemampuan Enoch sebagai penyaji (kubu tradisional) dan pencipta (kubu kontemporer) dinilai berhasil oleh Karna Yudibrata saat diwawancarai wartawan, Sudyarto yang memuatnya dalam tajuk headline koran Kompas berjudul "Enoch Atmadibrata, Benih yang Tumbuh di Atas Tanah Tandus" pada tanggal 20 September 1977, menilai: "Pak Enoch adalah tokoh yang membanggakan saya. Di satu pihak ia adalah tokoh yang konsepsionil dalam penciptaan. Di pihak lain ia adalah orang yang tradisional plus" (Sudyarto, 1977:5)

Skill dan knowledge pada sosok Enoch tidak sekedar membawanya menjadi seniman penyaji dan pencipta, tetapi juga mampu mendudukan sebagai seniman pendidik dan pemikir. Sangat jarang menemukan dua aspek kompetensi yang balans seperti diperlihatkan Enoch pada aspek performance (keterampilan yang dapat dilihat secara langsung) dan aspek rasional (kemampuan yang tidak dapat dilihat secara langsung, seperti ide kreatif, wawasan dan pengetahuan). Dua aspek kompetensi yang menjadi dua sisi mata koin yang berbeda namun merupakan satu kesatuan utuh, dijelaskan Gulo sebagai berikut:

Kompetensi dalam aspek yang nampak disebut performance (penampilan). Performance ini tampil dalam bentuk tingkah laku yang dapat didemonstrasikan sehingga dapat diamati, dilihat, dan dirasakan. Karena sifatnya yang demikian, maka kompetensi dalam arti performance dapat ditangkap oleh semua orang ${ }^{3}$...Sedangkan kompetensi dalam arti yang tidak nampak disebut kompetensi dalam aspek rasional. Kompetensi dalam aspek ini tidak dapat diamati karena tidak tampil dalam bentuk yang empiris $^{4}$ (Gulo, 2005:34).

Keberhasilan menjalankan peranan sebagai seniman penyaji, pencipta, pendidik, dan pemikir, memberikan stimulus kepada seniman generasi muda, di antaranya Gugum Gumbira dan Zaeni Alif. Gumbira menyatakan "Pak Enoch adalah guru saya. Beliau yang menginspirasi saya untuk bisa berhasil dan menjadi seniman seperti sekarang ini." ${ }^{5}$ Kehadiran Enoch yang berpengaruh positif terhadap seniman muda dirasakan pendiri Komunitas Hong, Zaeni Alif, yang berbeda jauh usia dan generasi dengan Enoch, menjalin komunikasi akrab pada tahun 2006 namun memberkas dengan kesan baik, yang secara implisit tersirat dalam pernyataannya kepada penulis "Jika saya menulis tentang 
pak Enoch maka tulisan tersebut berjudul: Enoch Sang Motivator" ${ }^{\prime 6}$

Fenomena Enoch sebagai seniman dengan derajat kompetensi menjadi menarik untuk dikaji ke dalam tulisan. Hasilnya tidak sekedar menceritakan kisah manis seniman menekuni profesinya atau taman bunga yang harum semerbak karena prestasi yang ditorehkan seniman Sunda bernama Enoch. Lebih dari itu, tulisan yang memberikan nilai suri tauladan dan berpretensi sebagai pendidikan karakter, dengan berkaca dari pengalaman orang lain. Hal yang selama ini urgen bagi generasi muda yang dikatakan tengah mengalami krisis keteladanan (Tilaar, 1998:105). ${ }^{7}$ Selebihnya tulisan ini memberikan informasi, wawasan, dan pengetahuan bagi calon seniman, mahasiswa, atau khalayak umum yang menaruh minat pada masalah pencapaian derajat kompetensi di kalangan seniman. Berkaitan dengan kajian tersebut, maka pembahasan pada tulisan dirumuskan dalam bentuk pertanyaan: (1) Seperti apa kompetensi yang dimiliki Enoch; dan (2) Bagaimana bentuk kontribusi selama berprofesi sebagai seniman?

\section{PEMBAHASAN}

\section{Kompetensi Enoch Atmadibrata Sebagai} Seniman

Brinner dan Gulo mensyaratkan dua aspek yang teridentifikasi diampu oleh seniman yang kompeten pada keprofesiannya. Dua aspek yang diistilah Brinner sebagai skill dan knowledge, secara semantik oleh Gulo diistilahkan sebagai aspek performance dan rasional. Meskipun pengucapan berbeda namun pengklasifikasian aspek kompetensi dari Brinner dan Gulo merujuk pada makna istilah yang sama. ${ }^{8}$ Aspek performance tidak lain adalah skill, teraktualisasi dalam bentuk tingkah laku yang didemonstrasikan sehingga dapat diamati, dilihat, dan dirasakan; sedangkan aspek rasional adalah knowledge, karena berkaitan dengan ide gagasan dan pengetahuan, yang tidak tampil secara empiris.
Kaitannya dengan Enoch yang menjadi objek material dalam tulisan ini, dipandang berhasil mengaktualisasikan diri sebagai seniman yang mencapai derajat kompetensi dengan kekaryaan yang memberikan sumbangsih terhadap keberlangsungan, perkembangan, dan pembaharuan kekaryaan pada kesenian di Jawa Barat. Kompetensinya itu tidak sekedar dimanfaatkan oleh masyarakat Jawa Barat, tetapi dimanfaatkan juga dalam pergaulan yang bersangkutan dengan dunia seni dan pendidikan pada tingkat regional, nasional dan internasional. Hal ini dapat dilihat dari bahasan kekaryaan Enoch sebagai seniman penyaji, pencipta, pemikir, dan pendidik yang teraktualisasikan dari aspek performance dan aspek rasional yang sebagai berikut: 


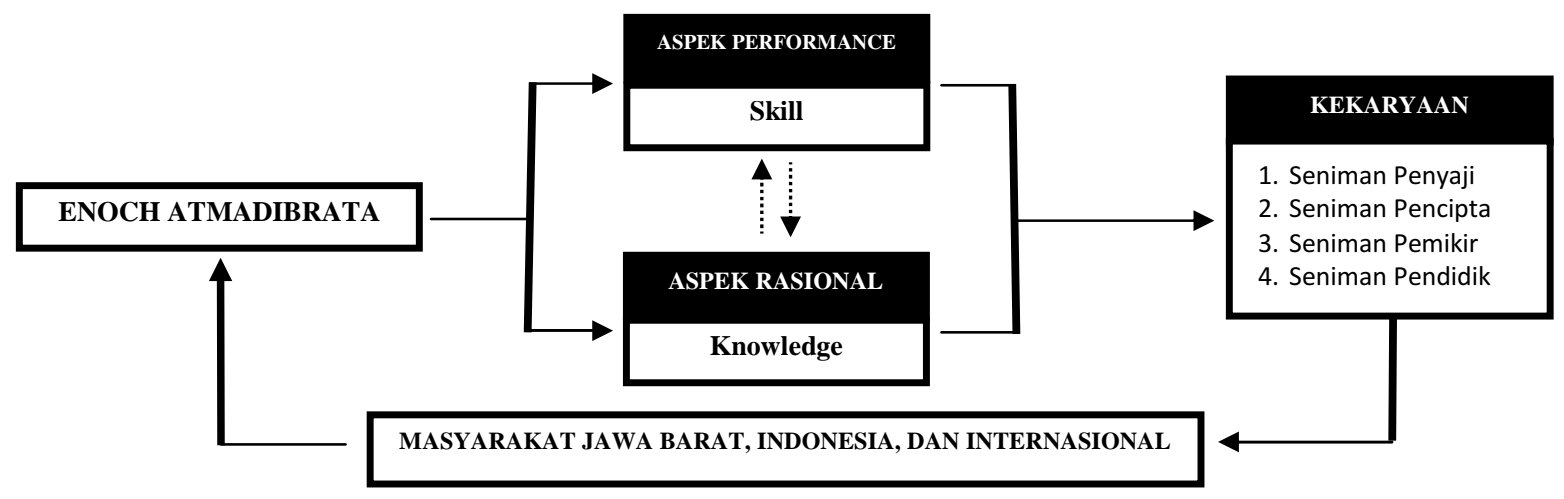

Skema 1. Kompetensi kesenimanan Enoch Atmadibrata menghasilkan kekaryaan yang berkontribusi pada Kesenian Jawa Barat
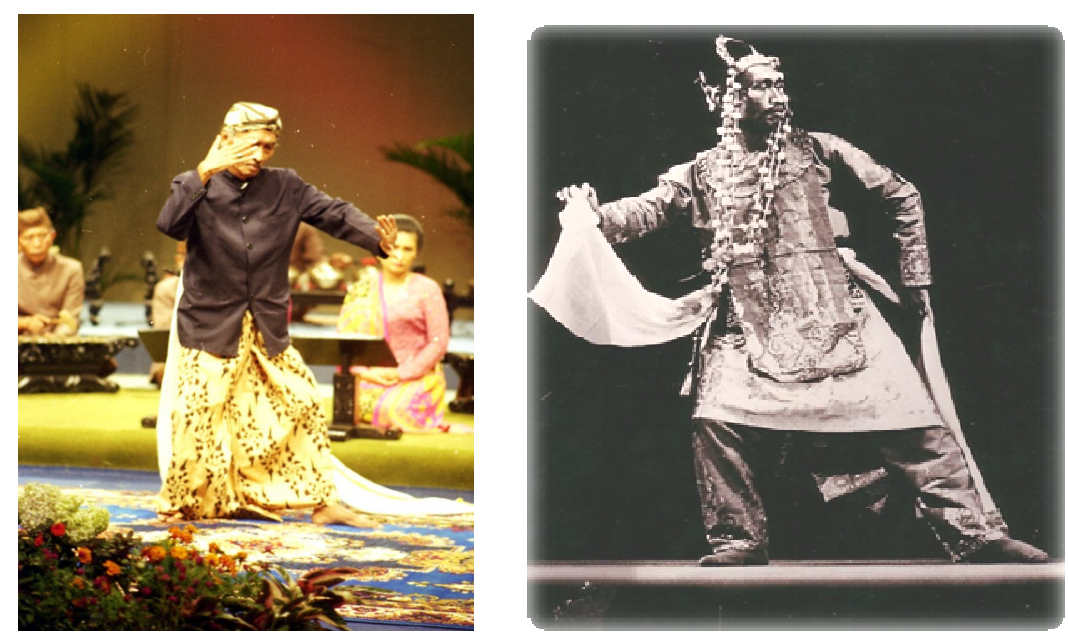

Gambar 1. Enoch menari Keurseus di TVRI Jabar pada tahun 1997 (kiri) dan Enoch menari Topeng Klana gaya Cirebon di Amerika tahun 1970 (kanan) (Dok. Enoch Atmadibrata)

\section{Kekaryaan Enoch Sebagai Seniman Penyaji}

Seniman yang bertindak sebagai penyaji menekuni kesenian yang melembaga, mengkristal, dan mentradisi dalam kehidupan sosial budaya masyarakatnya. Mereka mewarisi skill dan knowledge dari generasi seniman terdahulu, dengan mengimitasi skill dan praktik garap yang menjadi konsensus bersama. Proses imitasi dimulai Enoch dengan belajar tari keurseus kepada Rd. Sambas Wirakusumah dan Rd. Sari Redman pada tahun 1950 di perkumpulan Wirahmasari Puseur Rancaekek dan Wirahmasari Cabang Bandung; pada tahun 1951 belajar tari kepada Rd. Cece Somantri diwadahi Badan Kesenian Indonesia (BKI) yang bertempat di Gedung Yayasan Pusat Kebudayaan (YPK) Bandung, dan pada tahun 1957 belajar tari Topeng Cirebon kepada Bi Dasih dari Palimanan Cirebon (Rosidi, 2000:220). Kemampuan Enoch sebagai penyaji kerap dipertunjukkan dalam misi kesenian baik pada tingkat regional, nasional, maupun internasional. Loyalitas pada bidang ini dijalani Enoch hingga akhir hayatnya, di mana pada akhirnya ia 
berperan mentransmisikan skill dan knowledge kepada generasi muda yang berminat menjadi seniman penyaji di padepokan yang didirikan bersebelahan dengan rumahnya.

Enoch adalah penari yang piawai dalam praktik Karawitan Sunda. ${ }^{9}$ Pada tahun 1950, saat menjadi mahasiswa Universiteit van Indonesie pada Facuiteit van Exacte Wetenschap (Fakultas Ilmu Pengetahuan Teknik) dengan jurusan Werktuigkunde (Mesin) - sekarang Jurusan Teknik pada Institut Teknologi Bandung (ITB) Enoch patungan dengan para mahasiswa membeli seperangkat gamelan degung dari bahan besi dan belajar menabuhnya kepada sang penjual bernama Mang Uye, pemain suling dari rombongan Degung Purbasasaka pimpinan Abah Oyo (Atmadibrata, 2005:2 dan Risyani, 2008:163). Selanjutnya belajar gamelan degung kepada Abah Oyo pada tahun 1956 (Sukanda, 1991:91). Skill menabuh gamelan degung diaplikasikan saat mengiringi Tari Cendrawasih (tarian ciptaan Enoch) yang dipertunjukkan untuk pertama kali di hadapan Bung Karno dan Perdana Menteri Uni Soviet, Nikita Kruschev, di Bumi Sangkuriang (Redaksi Tempo, 1981:59). Enoch menjadi seniman penyaji pada gamelan degung yang beranggotakan nayaga dari Daya Mahasiswa Sunda (Damas), yakni Surachman pada saron, Dedi Jamhur pada panerus, Koswara pada salentem, Kendang oleh Kosasih, peniup suling adalah Sukanda, Komar pada kacapi, dan Enoch sendiri memainkan bonang (Risyani, 2008:170).
Pada perjalanan selanjutnya Enoch menjadi penyaji pada suling dengan mempelajari instrumen aerophone tersebut kepada Sukanda; juga belajar kacapi indung kepada ibu Haji Siti Rokayah, serta mendalami mamaos kepada suami ibu Haji Siti Rokayah bernama H. Mamat Soelaeman. Kemampuan dalam seni mamaos hanya diperlihatkan Enoch ketika misi kesenian di luar negeri atau karena ketiadaan personil yang menabuh kacapi atau suling (dipresentasikan saat emergency). Kemampuan pada seni mamaos berikut dengan instrumen pengiringnya ditularkan Enoch di lingkungan keluarga dan Padepokan Seni Tutuka yang dikelola sejak tahun 1988, salah satunya diturunkan kepada sang anak, bernama Asep Nugraha.

Kemampuan sebagai seniman penyaji pada seni Karawitan diaplikasikan Enoch saat mengajar pada Studiclub Teater Bandung (STB) dan Akademi Teater dan Film (ATF) Bandung, di mana dalam pementasan STB dan ATF, Enoch mewarnai pertunjukan dengan koregrafi yang diiringi aransemen musik yang diciptakannya, mengaplikasikan media gamelan degung dan kacapi suling. Peristiwa itu disaksikan Cornelia J. Benny yang menulis sepak terjang Enoch sebagai penyaji pada Karawitan dan Koregrafer pada pertunjukan teater sebagai berikut:

Noch pernah mengajar di STB selain itu beliau mengajar pula di ATF Bandung. Tidak heran bila beliau amat dekat dengan para sineas. Noch turut pula berkarya bersama Jim Liem (Jim Adhi Limas) dalam pergelaran Tiga Babak 
Drama Jepang dan mengiringi drama tersebut dengan kacapi surupan sorog. Pernah juga secara khusus bunyi alat kacapi dihadirkan Noch pada ilustrasi sebuah pegelaran teater berjudul Bangau Senja. Masih bekerja sama dengan Jim Liem, Noch menggarap pertunjukan teater berjudul Jaka Tumbal (1966). Selain itu ada pula pertunjukan Caligula yang melibatkan siswa dan pengajar STB (Studi Club Teater Bandung) sebagai pemain dan Noch-lah yang mengerjakan skenario, koreografi sekaligus memberikan pemikiran serta masukan untuk penatan musik iringan pergelaran tersebut (Benny, 2004:3-4).

Kompetensi Enoch mempresentasikan diri sebagai penyaji Karawitan yang disaksikan Cornelia pada kutipan di atas, terdokumentasikan Mantle Hood dalam buku The Ethnomusicologist (1971), dan poto saat memimpin rombongan kesenian Indonesia mengikuti Expo di Jepang selama enam bulan (1985). Kedua poto tersebut merekam aktivitas Enoch memainkan instrumen Karawitan Sunda, yakni suling dan kacapi.

Enoch memainkan suling

(dipindai dari buku The

Ethnomusicologist (1971) karya Mantle Hood)

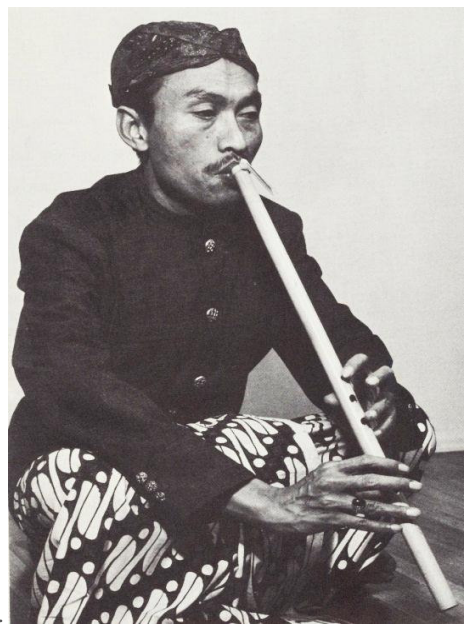

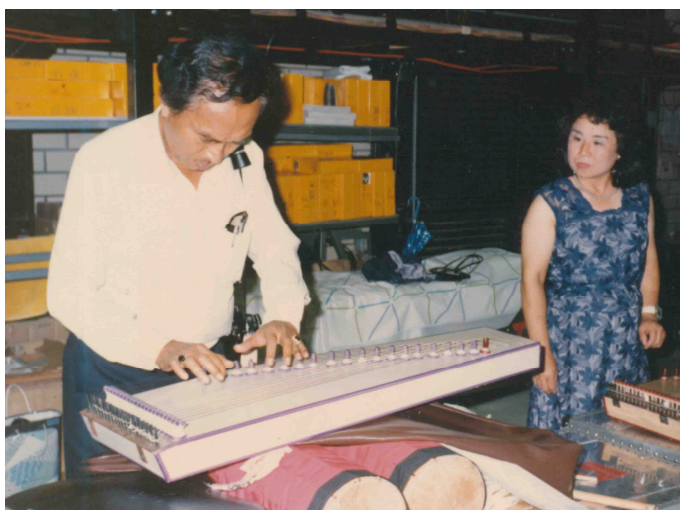

Gambar 3. Enoch memainkan kacapi di Jepang pada saat Expo'85 (Dok. Enoch Atmadibrata)

Enoch menjalankan peranan sebagai seniman penyaji, pada praktiknya tidak berkutat pada tataran praktik yang mengaktualisasikan skill psikomotorik semata, akan tetapi memanfaatkan aspek rasional yang ada dalam dirinya, dengan memahami 'kedalaman' yang dapat digali dari seni tradisi yang ditekuninya. Ia mencoba mengidentifikasi hal yang bersifat teoritik dan konsep yang berabad-abad tertutup oleh budaya oral dan taken for granted pada kehidupan para pemilik dan pelaku kesenian di Jawa Barat. Secara perlahan tapi pasti, Enoch menjadi pionir orang Sunda dalam mengungkap, mengidentifikasi, mengklasifikasi, menjelaskan, menganalisis fenomena kesenian tradisional Jawa Barat yang dirumuskan secara sistematis ke dalam wujud tulisan. Bahkan mampu menginventaris 300 jenis kesenian tradisional di Jawa Barat termasuk Banten melalui Proyek Penunjang Peningkatan Kebudayaan yang dipimpinnya. Selama mendudukan diri sebagai pendidik yang mengajarkan seni tradisi, tentunya temuan hal yang bersifat teoritis dan konsep menjadi materi knowledge yang sangat 
penting untuk ditransmisikan kepada mahasiswa. Hal itu dapat dicermati pada diktat perkuliahan yang dibuatnya.

\section{Kekaryaan Enoch Sebagai Seniman Pencipta}

Bahasan di atas sedikit menyinggung salah satu aktivitas Enoch yang berperan sebagai seniman pencipta, yakni koreografer dan penata musik pada pergelaran seni Teater yang ditelorkan STB dan ATF Bandung. Sebenarnya aktivitas membuat koreografi telah dirintis sejak tahun 1955, yakni menciptakan tari Gatotkaca Skipu (peperangan antara Gatotkaca dengan Patih Sakipu) pada acara ulang tahun Wirahmasari di Gedung YPK Bandung; dan menata tarian Gending Karesmen Damarwulan Menak Jingga dan Gending Karesmen Mundinglaya yang disutradarai Rd. Sukarna; ${ }^{10}$ pada tahun 1957 membuat koreografi Lutung untuk Gending Karesmen Lutung Kasarung karya RTA Sunarya yang ditonton Presiden RI. Ir. Soekarno di lapangan sepak bola Uitspaning Na Ispaning (UNI) Bandung; pada tahun yang sama menciptakan Tari Cendrawasih yang dipertunjukkan di hadapan Perdana Menteri Uni Soviet, Nikita Kruschev di Bumi Sangkuriang; pada tahun 1958 menata koreografi Wayang Orang Sunda Jabang Tutuka dipertunjukkan di Gedung Bioskop REX Jalan Merdeka Bandung, didanai hasil penjualan karcis para anggota Damas; pada tahun 1960 menciptakan Tari Katumbiri yang dipentaskan pada Pekan Mahasiswa di Jogjakarta dengan personil adalah anggota Damas; pada tahun 1961 membuat koreografi fragmen Mundinglaya di Muara Beres naskah Wahyu Wibisana sebagai pengisi waktu pada Pasanggiri Ibing Sunda yang diselenggarakan Damas; pada tahun 1963 menjadi koreografer pada Gending Karesmen Mundinglaya Saba Langit dan Gending Karesmen Inten Dewata - kedua naskah dibuat Wachyu Wibisana - dan tahun 1964 menata tarian pada Gending Karesmen Galunggung Ngadeg Tumenggung juga naskah Wahyu Wibisana; tahun 1965 menjadi Sutradara dan penata tari Sendratari Mundinglaya disponsori UNPAR; pada tahun 1966 menjadi koreografer dan penata musik Drama Bersajak berjudul Geusan Ulun, naskah Saini KM, disutradarai Jim Lim, diperankan oleh mahasiswa ATF Bandung; tahun 1967 menjadi Sutradara dan pembuat naskah Dramatari berjudul Sangkuriang Kabeurangan dimainkan mahasiswa KORI dan Udjo Ngalagena (teman semasa SMP Enoch) yang melatih angklung di lapangan Sepak Bola PN Kertas Padalarang; tahun 1967 membuat koreografi Tari Hujan Munggaran dengan penata Gending Koko Koswara, dipentaskan siswa SMKI di Gedung Merdeka Bandung, di kediaman Gubernur Jakarta Ali Sadikin, di Banjar Ciamis dengan karcis yang laku terjual; tahun 1968 dan 1969 menjadi koreografer pada Sendratari Lutung Kasarung oleh mahasiswa KORI Bandung di Gedung Merdeka dan Kolam Renang Karang Setra Bandung; tahun 1982 menyutradarai Sendratari Sangkuriang yang diperankan mahasiswa IKIP Bandung di Lapangan terbuka 
IKIP Bandung; pada tahun 1983 menyutradarai pagelaran Karesmen Lutung Kasarung melibatkan Damas, mahasiswa ASTI Bandung, siswa SMKI Bandung, mahasiswa IKIP Bandung, LSS ITB, Lises UNPAD, Bina Budaya Galih Pakuan Jabar, Jugala, dan Mayang Binekas; pada tahun 1984 menjadi Sutradara sekaligus Penata Tari Oratorium Pejuang Bandung Utara dibawakan para mahasiswa Jurusan Tari FKSS IKIP Bandung di pentaskan di depan gedung Isola; pada tahun 1990 menyutradarai Gending Karesmen Lalayang Salaka Domas yang dihadiri Menteri Pendayagunaan Aparatur Negara, Ir. Sarwono Kusumaatmadja dan Gubernur Jabar Yogie SM di Hotel Homan Bandung; pada tahun 2001 menjadi Sutradara Setra Karesmen Nyi Pohaci Sanghyang Sri bertempat di auditorium RRI Bandung dan terakhir tahun 2006 menyutradarai Karesmen Gurat Tapak Ingkeun Ngagurat Tapak di pentaskan oleh Pemerintahan Kota Cimahi pada malam tahun baru. ${ }^{11}$

Kemampuan menjadi seniman pencipta pada kekaryaan di atas merupakan bukti bahwa rangsangan kreatif yang diresepsi Enoch mampu ditransmisikan ke dalam wujud kekaryaan dengan menggunakan medium pokok gerak (pada tari) atau bunyi (penataan musik teater) berdasarkan prinsip estetik, melalui proses imajinasi, ide, tujuan penciptaan, dan proses kreatif. Hasilnya adalah bentuk kekaryaan yang dikomunikasikan Enoch kepada masyarakatnya. Walaupun apresiasi masyarakat menerima karya dengan wujud relatif baru (kontemporer) pada masa itu masih belum banyak yang bisa memahami terutama yang kental pada kubu tradisi (Atmadibrata, 1996:2). Pada karya Tari Cendrawasih (1957) misalnya, Enoch menawarkan pola ritmik baru dari frase melodi gamelan degung klasik yang diinterpretasi dan direspon sebagai patokan gerak pada tarian, hal yang berbeda dengan konsesus tari Sunda pada masa itu yang menggunakan kendang sebagai pola ritmik. Fenomena ini ditulis Enoch dalam surat kepada Tony Donaldson, mahasiswa Victoria University of Wellington yang menulis tesis berjudul The Shaping of Sundanese Music and Dance Tradition: an Ethnomusicological Study of Pa Enoch Atmadibrata (1994) sebagai berikut:

This will be very difficult to explain in relation with the rhythmic patterns, the relate degung rhythmic patterns to my inovation with the dance is, what I mean by degung rhythmic pattern is those what feel stimulated by every litlest motief of the degung piece. It isn't the drum pattern for dance in the pelog or salendro gamelan, as the usual way in the classical Sundanese dances. We call it 'Wirahma Kendang'. So in Cendrawasih dance the movements or dance frases are not bound to the drumpattern, but to the melodic phrases with their motiefs.

Perjalanan Enoch dalam mencipta tarian dan iringan gamelan degung diikuti Andrew Weintraub sebagai peneliti asing yang menyebut "Enoch Atmadibrata is the first Sundanese artist to combine this type of gamelan degung with dance" (Weintraub, 1985:4). Tarian yang tidak 
bergantung pada tabuhan kendang menjadi ciri khas kekaryaan Enoch selanjutnya, seperti pada Tari Katumbiri (1960) dan Hujan Munggaran (1967). Setiap penari yang membawakan tarian dari kekaryaan Enoch benar-benar harus paham pada musikalitas garap karawitan yang menjadi pengiringnya. Itulah tantangan yang berhasil diterapkan Enoch dalam mencipta kekaryaan tarian maupun Gending Karesmen, termasuk berkolaborasi dengan Koko Koswara tokoh pembaharu Karawitan Sunda yang menciptakan gamelan wanda anyar (Enoch adalah satusatunya seniman tari yang dipercaya Koko Koswara membuat koreografi tarian pada Gending Wanda Anyar). Peristiwa Enoch mencoba memahami gending wanda anyar untuk direspon ke dalam kekaryaan serta respon dari Mang Koko terhadap hasil kekaryaan Enoch, ditulis dalam surat Enoch kepada Tony Donaldson sebagai berikut:

After about one month, Mang Koko was finished with the whole music piece. I studied the music by using tape recorder. I try to make drawing in accordance with my imagination after several time listening to the rich ornamentation which appeared to me as motiefs different from that of degung. Then I marked the phrase which might be a After several time listening guidance for making dance phrases. After about two weeks I feel I can start with training the dance. After seeing the dance, Mang Koko was surprised and said that it was beyond his imagination, that his music can fit to a dance what he witnessed. Fortunately there was an opportunity to perform it on an important occasion.

Peristiwa bersejarah seorang koreografer yang bekerja sama dengan Mang Koko dicatat dan dikomentari Nano Suratno dalam makalah berjudul "Sabundeureun Karawitan Tari Sunda" (1980), yang ternyata mampu memberikan stimulus kepada koreografer muda pada saat itu. Tulisan Nano S dikutip sebagai berikut:

Hiji hal nu perlu dicatet, gawe babarengan sacara khusus antara Mang Koko jeung Enoch Atmadibrata, dina Tari Hujan Munggaran. Gending sacara 'utuh' diropea, disawang, dicipta gerakgerakna, nepi jadi awor dina hiji komposisi tari. Saperti pangakuan Enoch, nyipta tari saperti kieu mibutuh kacermatan, katalitian, jeung rasa Karawitan nu 'mendalam'. Gending teh teu sirikna dijejer-jejer heula, kitu ceuk pangakuan Enoch Atmadibrata. Rek kumaha bae carana, eta mah cara masing-masing indipidu. Ngan nu jelas eta karya babarengan teh geus mere sinar anyar, boh keur kreasi tari, boh keur karawitan. Pangaruh tari anu ngicip-ngicip gending, anu saterusna diangkat kana gerak-gerak tari, di antarana kasebut ngarana Yus Rusliana (Nano S, 1980:9).

Kekaryaan Enoch sebagai pencipta yang produktif dari tahun 1955-1963, membuahkan kepercayaan Rd. Cece Somantri, yang mengajak Enoch menjadi asistennya mengajar di Konservatori Karawitan (KOKAR) Bandung, yakni pada 
pelajaran Tari Gubahan Baru (Risyani, 2008:162). Setelah Rd. Cece Somantri meninggal, Enoch menggantikan secara permanen mengajar di KOKAR, di situlah Enoch menjalin hubungan akrab dengan Koko Koswara yang kemudian menjadi atasannya.

\section{Kekaryaan Enoch Sebagai Seniman Pemikir $^{12}$}

Kemampuan Enoch sebagai pemikir dan pemimpin ditempa saat bergabung dengan organisasi Damas, memimpin Bagian Kebudayaan Damas dari tahun 1957-1963. Bidang kebudayaan sebagai bidang baru, mengharuskannya berakselerasi mengejar ketertinggalan dalam wawasan budaya Sunda. Cara Enoch adalah membina hubungan baik dengan Badan Pengulik Budaya (BPB) Kiwari dan Nonoman Sunda, memfasilitasi mereka sebuah tempat berdiskusi dan bertukar pendapat di rumah yang berlokasi di jalan Sasak Gantung Bandung, rumah yang difungsikan anggota Damas wanita berlatih gamelan degung pada siang hari (Enoch Atmadibrata, 1999:52), menjadi ramai dengan obrolan hangat yang menjurus perdebatan pada malam hari. Momentum tersebut dimanfaatkan Enoch berpikir kritis, menuangkan gagasan, dan berdiskusi memperkaya wawasan dari isu kebudayaan yang ketika itu menjadi cita-cita bersama untuk mewujudkan Sundanologi. Aktifitas para pemuda di rumah yang diberi nama Sayang Kalong $^{13}$ dituliskan Saini KM dalam Harian Umum Pikiran Rakyat (1984) sebagai berikut:
Pemerkasa BPB Kiwari adalah sastrawan budayawan Ajip Rosidi yang menghimpun anggota: Rukasah, Atja, Ramadhan K.H., Yus Rusamsi, Saini KM., dan Popo Iskandar. Pada saat itu Nonoman Sunda dan Damas melakukan kegiatan yang sama, meskipun Damas lebih memusatkan pada kegiatan kesenian. Anggota BPK Kiwari, Nonoman Sunda, dan Damas melakukan kerja sama dan hubungan pribadi yang akrab. Enoch Atmadibrata sebagai tokoh Lingkung Seni Damas tidaklah asing bagi orang-orang BPB Kiwari. Pada masa-masa tertentu, di jalan Sasak Gantung, terdapat semacam studio kesenian yang dikenal dengan sebutan Sayang Kalong. Anggota Kiwari dan Damas berdiskusi (bergulau) belaka. Jelas lalu lintas pikiran terjadi dengan intensif dan dapat dipastikan pada saat itu cita-cita mewujudkan Sundanologi sudah semakin tumbuh (Saini KM, Pikiran Rakyat, 8 Juni 1984)

Kegiatan diskusi membiasakan berpikir kritis dan berani mengeluarkan pendapat, ${ }^{14}$ termasuk Enoch yang menikmati aktivitas tersebut. Hasilnya dituangkan dalam tulisan yang dimuat surat kabar lokal, 'mengangkat nama' para pemuda yang tergabung dalam organisasi Damas, BPK Kiwari, dan Nonoman Sunda, menjadi dikenal oleh publik luas. Tulisan yang dimuat disanggah rekan lain melalui tulisan pada Surat Kabar terbitan berikutnya. Sanggahan itu tidak serta merta diterima, tetapi dipertahankan dengan tulisan berikutnya, saling membalas satu dengan yang lain, sehingga tercipta perang opini, yang kadang teraktual di 
'mata' masyarakat seperti kubu yang bermusuhan, bukan debat kusir, tetapi menyertakan logika berpikir yang menghangatkan perkembangan intelektual pemuda Sunda pada masa itu. Di sisi lain, masyarakat yang mengkonsumsi perdebatan, terdidik pula berpikir kritis, terutama memandang isue kebudayaan yang ditinjau dari berbagai perspeksif yang logis, diperdebatan, dan diwacanakan melalui tulisan bersifat reciprocal (timbal balik). ${ }^{15}$ Selebihnya bagi personal yang terlibat dalam perdebatan, tercipta saling melengkapi pemikiran, juga pengimplementasian simbiosis mutualisme yang disebut Enoch: "silih ngagedekeun ngaran, ku silih kritik di koran" (Indonesia: saling membesarkan nama masing-masing). Secara sadar atau tidak sadar mereka telah membentuk menejemen konflik yang mengangkat pencitraan mereka di hadapan khalayak ramai dari perdebatan intelektual (bukan perdebatan politik seperti yang kita saksikan di media televisi dewasa ini). Mereka yang terlibat perdebatan panas pada media cetak itu, tetap bercengkrama dengan akrab dalam pergaulan sehari-hari. Suatu kondisi yang kondusif yang tidak bisa diinterpretasi para pembaca jika membaca tulisan di koran.

Pergaulan dengan para intelektual muda di kelompok Sayang Kalong berhasil mendudukan Enoch sebagai seniman yang mampu menyusun konsep dan hal yang bersifat teoritik ke dalam bentuk tulisan maupun lisan. Enoch menjadi Pimpinan Redaksi Majalah Bulanan Haruman: Pengemban Pancasila \& Pengabdi
Ampera (1966) dengan wakil Saini Karnamisastra (Saini KM) dan Iton Kach Jayawisastra, sedangkan anggota Staf redaksi adalah Wahyu Wibisana, Eddy H.S., Dadang Sulaeman, Ubun Syachbun, dan Yayat Hendayana; adapun pembuat ilustrasi gambar adalah Ganjar Sakri dan Dedy Suardi. ${ }^{16}$

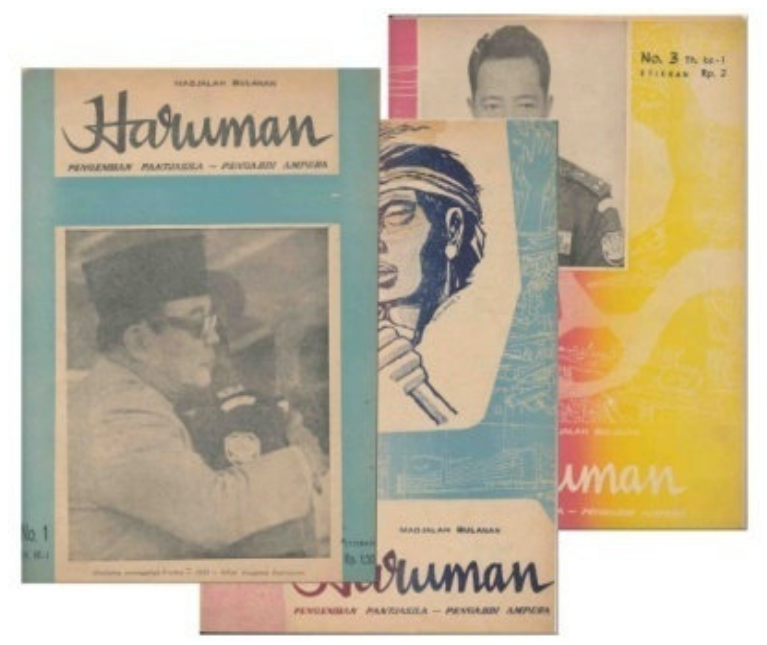

Gambar 4. Majalah Bulanan Haruman (1966-1968) di bawah kepemimpinan Enoch Atmadibrata

$$
\text { Pada tahun 1974-2005 menjadi }
$$
pimimpin Majalah Buletin Kebudayaan Jawa Barat Kawit, di sini Enoch menularkan pengetahuannya dalam penelitian yang mengkaji dengan pendekatan Etnomusikologi - hasil studi selama tiga tahun di UCLA - kepada peneliti generasi muda, seperti Ali Sastraamijaya, Endo Suanda, Mumung, Roni Ardiwijaya, Joni Nurendah, Atik Soepandi, Tatang Suryana, dan Kiki Sukanta. Pada mulanya buletin kebudayaan Kawit mendapatkan bantuan dana operasional dari pemerintah propinsi Jawa Barat, namun setelah bantuan diberhentikan akibat kebijakan pemerintah propinsi yang baru, dana 
operasional penerbitan berjalan dari saku pribadi Enoch.

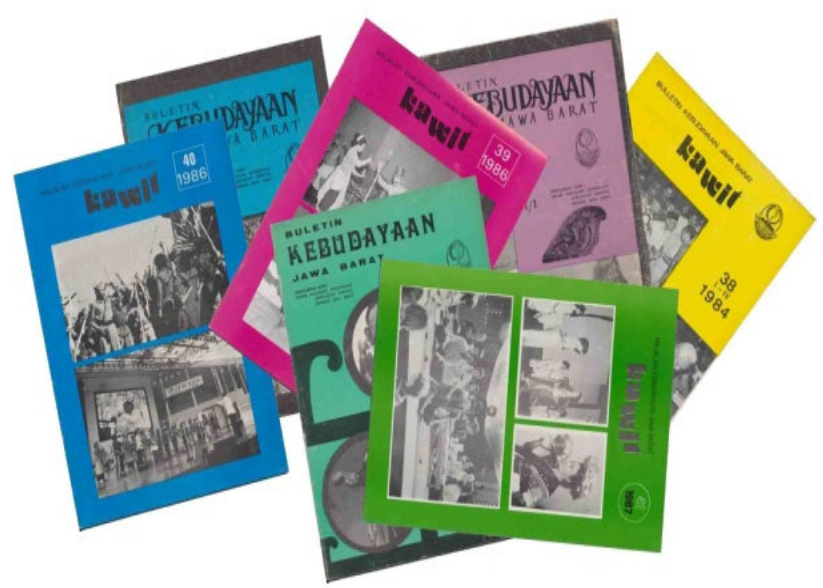

Gambar 5 Buletin Kebudayaan Jawa Barat Kawit (1974-2005) di bawah kepemimpinan Enoch Atmadibrata

Selama tujuh tahun (1984-1991), Enoch mendapat kepercayaan Jamer R. Brandon menjadi contributing editor pada Asian Theatere Journal, sebuah jurnal internasional afiliasi dari beberapa Perguruan Tinggi di Amerika University of Hawai, University of New York, University of California Santa Cruz, University of Kansas, University of Colorado, University of Wisconsin Madison, University of Texas, University of Rome - yang konsern mengkaji Teater di Asia. Afiliasi berkembang tidak hanya bentuk kerjasama Perguruan Tinggi di Amerika, tetapi dengan Perguruan Tinggi Seni di belahan dunia lainnya, antara lain: Ateno de Manila University, Beijing Institut of Chininese Opera Research, Maioson des Cultures du Monde Paris, Shochiku Theatrical Corp Tokyo, dan Chulalongkorn University Bangkok. Jurnal ini masih eksis hingga sekarang (2014) di bawah pimpinan Kathy Foley sebagai Editor utama. Namun disayangkan minus Editor yang berasal dari Indonesia.

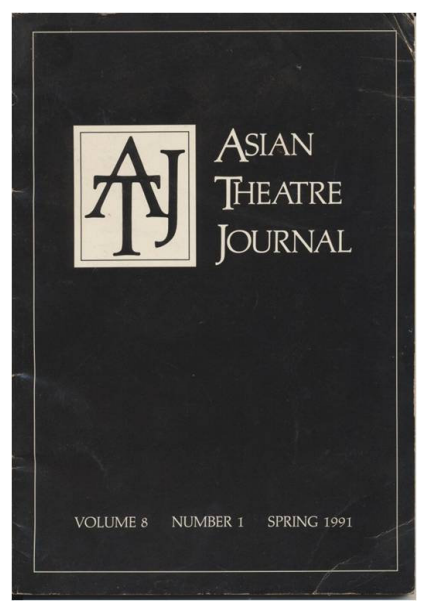

Gambar 6. Asian Theatre Journal, di mana Enoch dari tahun 1984-1991 sempat menjadi Editor bekerjasama dengan James R. Brandon

Enoch menjadi pembicara pada Seminar internasional yang bertajuk Seminar of the Center for South Pasific Studies atas undangan David B. Kilpatrick, University of California Santa Cruz pada tanggal 18-22 Mei 1977. Undangan Kilpatrick disambut gembira dengan surat balasan Enoch yang dikutip sebagai berikut:

Dear Dr. David B. Kilpatrick, your invitation to me for participation in the Conference of the South Pacific Studies at USCS surprised me very much. I will be preparing for presenting a peper or lecture-demonstration, and thank you very much for the invitation. This theme "Acculturation and the Performing arts in the Pacific Islands" sound to be very rare and has never been exposed in Indonesia, and this is what interest me very much. I would to expose you a list of facts which I thought as related to 
acculturation in West Java...(letter from Atmadibrata 8 Februari 1977).

Tema akulturasi seperti tertulis dalam surat kepada Kilpatrick di atas mendudukannya sebagai seniman Indonesia yang mampu berbicara' dalam percaturan dunia Internasional. Undangan sebagai pembicara kembali datang dari SPAFA Workshop yang berkantor di Bangkok Thailand pada tahun 1979, bersama pembicara rekan satu Almamater di UCLA, yakni Drs. Soedarsono, dan Bapak Pendiri KONRI Surakarta (ISI Surakarta), Dr. S.D. Gendon Humardani. Kemudian pada tahun 1983 Enoch menjadi satu-satu penceramah dari Indonesia yang berkesempatan memberikan lecture-demonstration pada Festival Asean di Kuala Lumpur Malaysia. Pembicara pada Seminar Internasional, dilakoni Enoch untuk terakhir kali pada Konferensi Internasional Budaya Sunda (KIBS) ke-1 yang diselenggarakan Ajip Rosidi di Gedung Merdeka Bandung, Jawa Barat, Indonesia, pada tahun 2000.

\section{Kekaryaan Enoch Sebagai Seniman Pendidik}

Enoch secara khusus menjadi pendidik seni pada sekolah formal dan Perguruan Tinggi: Tahun 1953 mengajar Kesenian Daerah di Sekolah Guru Bagian A (SGA) dan Sekolah Guru Bagian B (SGB) pada pelajaran Tari Keurseus dan Tari Karya Cece Somantri (Komala, 2013:240); Tahun 1963 menjadi Guru pada pelajaran Tari Gubahan Baru di KOKAR Bandung direkomendasikan Cece Somantri dengan
Surat Keputusan (SK) ditandatangani Koko Koswara; pada tahun yang sama SK Nomor 243/SK.LKUP/63 ditandatangani Drs. Barli Sasmitawinata mendudukan Enoch sebagai pengajar tari pada Universitas Pajajaran (UNPAD) Bandung; Kesibukan Enoch di tahun 1963 semakin bertambah dengan terbitnya SK Nomor 1339/C/P/63 ditandatangani Kepala Jawatan Kebudayaan Departemen Pendidikan dan Kebudayaan yang menempatkan Enoch menjadi Guru Tidak Tetap Pada Konservatori Tari Jogjakarta mengajar Praktik Tari selama 6 jam; disusul SK Nomor: 1538/C/P/63 yang mengangkat Enoch menjadi Dosen Tidak Tetap pada ASTI Jogjakarta mengajar Praktik tari untuk 8 jam Mata Kuliah; SK selanjutnya bernomor II/63-12/56-8p mengangkat Enoch menjadi Pelatih Tari dan Degung pada Universitas Parahiangan.

Sepulang menyelesaikan perkuliahan selama tiga tahun (1969-1971) di University of California Los Angeles pada The Institute of Ethnomusicology Amerika Seikat, ${ }^{17}$ pada pertengahan tahun 1971 menjadi Dosen Luar Biasa pada ASTI Jogjakarta Jurusan Sunda di Bandung; pada tahun 1978 mendapat SK dari Rektor UNPAD Nomor 1147/UP/13/78 menjadi Dosen Luar Biasa pada Mata Kuliah Film Production Fakultas Publisistik (Sekarang Fikom UNPAD); Tahun 1981, Keputusan Rektor IKIP Bandung Nomor 3948/PT.25.R/C/1981 mendudukan Enoch menjadi Ketua Jurusan Tari dan pengajar pada FKSS IKIP Bandung yang digagasnya, ia mengajar Mata Kuliah Penge- 
tahuan Tari, Media Pengajaran Tari, Tafsir Garap, dan Penelaahan Buku; pada tanggal 1 Desember 1987 menjadi kepala PPP Kesenian Lembud UNPAS dalam SK yang ditandatangani Rektor nomor: 059/Unpas.R/SK/C/XI/1988.

Karya Enoch sebagai pendidik yang dimanfaatkan banyak hingga sekarang, sebagai kontribusi dari buah pemikirannya, adalah keberadaan Konservatori Tari (KORI) di Bandung, yang dalam perjalanannya mengalami pergantian nama menjadi Akademi Seni Tari Indonesia (ASTI) Bandung, Sekolah Tinggi Seni Indonesia (STSI) Bandung, pada penghujung tahun 2014 berganti nama menjadi Institut Seni Budaya Indonesia (ISBI) Bandung. Perjuangan Enoch mendirikan KORI, sebagai satu-satunya
Perguruan Tinggi Seni di Jawa Barat pada tahun 1968 didasari keyakinan, bahwa aktivitas seni di Sunda tidak 'berhenti' pada ranah estetis semata, melainkan berpotensi masuk ke dalam dataran ilmu pengetahuan yang diwadahi lembaga pendidikan setingkat Perguruan Tinggi. ${ }^{18}$ Keyakinannya itu diperkuat Enoch dengan mengagas kembali pendirian institusi pendidikan yang mencetak mahasiswa untuk menjadi guru kesenian, yakni Fakultas Keguruan Sastra dan Seni (FKSS) Institut Keguruan Ilmu Pengetahuan (IKIP) Bandung (Sekarang Jurusan Pendidikan Seni Drama Tari dan Musik (Sendratasik) Universitas Pendidikan Indonesia (UPI) Bandung) pada tahun $1981 .^{19}$

\section{PENUTUP}

Enoch mendudukan diri sebagai seniman yang mampu mencapai derajat kompetensi dengan memanfaatkan skill dan knowledge yang ada pada dirinya. Aspek performance dan aspek rasional diejawantahkan ke dalam kekaryaan yang memberikan kontribusi kepada keberlangsungan kesenian - tari, karawitan, teater, dan dunia pendidikan - di Jawa Barat. Dedikasi dan kesetian terhadap keprofesian sebagai seniman jangan dipertanyakan apabila kita mencermati perjalanan panjang yang teraktualisasikan aktivitas Enoch sebagai seniman penyaji, pencipta, pemikir, dan pendidik. Tidak dapat disangkal bahwa Enoch adalah salah satu seniman sentral yang berhasil membawa seni Sunda menembus lapisan masyarakat internasional. Bahkan membawa seni Sunda untuk tidak berhenti pada dataran estetis, melainkan secara nyata telah masuk dataran ilmu pengetahuan dengan hasil yang mulai signifikan. Jurnal kesenian yang dulu dirintis Enoch, pada masa sekarang sudah banyak yang bermunculan dari hasil penelitian yang mendalam studi master dan doktoral para mahasiswa yang menempuh pendidikan pada institusi yang didirikan Enoch - KORI yang bermetamorfosis menjadi ISBI Bandung dan FKSS IKIP Bandung yang bertransmisi menjadi Jurusan Sendratasik UPI Bandung. Mudah-mudahan terwujudnya 
Sundanologi yang dicita-citakan Enoch pada masa lampau akan segera terealisasikan oleh para Profesor, Doktor, dan Megister Seni dari kedua institusi pendidikan yang sekarang telah menjadi 'besar' tersebut.

\section{CATATAN AKHIR}

1 Adanya pendikotomian antara seniman yang kompeten dengan seniman 'tukang', mengisyaratkan bahwa seorang seniman harus membuktikan diri dengan memperlihatkan kemampuan mereka di atas standar rata-rata para seniman yang sekedar disebut capable atau 'tukang'. Salah satu cara yang mendukung pembuktian itu adalah dengan proses belajar dari waktu ke waktu. Artinya, seniman bersangkutan senantiasa mengaplikasikan perubahan kualitas skill dan pengetahuan (knowledge) yang grafiknya diusahakan terus meningkat. Dalam rangka mewujudkan hal itu, dibutuhkan perjalanan waktu dan proses yang panjang. Tidak heran, seniman dengan derajat kompetensi begitu sedikit dibandingkan dengan jumlah seniman yang 'biasa' saja (Nugraha 2007:4)

${ }^{2}$ Resiko lain sebagai konsekwensi memilih profesi sebagai seniman adalah dimusuhi keluarga pada awal perintisan karier. Keluarga menilai Enoch memilih jalan hidup yang tidak marketable sebagai jaminan untuk memenuhi dan menjaga asap dapur tetap mengepul. Salah satu kakak lakilaki menyebut jalan hidup yang dipilih Enoch dengan ungkapan: hirup teu pararuguh (Indonesia: hidup yang tidak memiliki masa depan).

3 Melalui pengamatan dapat dibedakan kompetensi seorang dukun atau tukang pijat dengan kompetensi seorang dokter. Profesi tukang pijat, profesi dukun atau profesi dokter ketiga-tiganya berada dalam satu bidang, yaitu kesehatan. Akan tetapi tanpa harus belajar tentang ilmu kedokteran, seorang mengetahui bahwa dokter lebih kompeten dari tukang pijat dalam hal penyembuhan pasien.
${ }^{4}$ Seorang dokter yang tidak praktik dan tidak menggunakan atribut-atribut profesinya, tidak diketahui bahwa ia mempunyai kemampuan untuk mengobati suatu penyakit. Kalau anda kebetulan bertemu dengan dokter dalam keadaan demikian, maka tidak timbul kesan bahwa orang yang sedang anda hadapi adalah orang yang mempunyai kompetensi mengobati penyakit.

${ }^{5}$ Pernyataan Gugum Gumbira dalam Film Dokumenter Tapak Lacak 80 Tahun Enoch Atmadibrata (2007) produksi Yayasan Tikar Media Budaya Nusantara Bandung.

6 Wawancara dengan Zaeni Alif, pada tanggal 6 November 2012.

${ }^{7}$ Krisis Keteladan seperti fenomena yang tengah marak dewasa ini, di mana generasi muda yang kerap diberitakan di televisi dan menjadi publik figur yang memukau dan menjadi model yang dicontohkan para orang tua kepada anakanaknya agar berhasil menjalankan profesi seperti publik figur yang dimaksud, pada akhirnya tersandung masalah korupsi. Belum lepas dari ingatan kita, baru-baru ini kita dihadapkan pada pemberitaan Nazarudin, Anas Urbaningrum, dan Angelina Sondakh, masih muda, tampan dan cantik, sukses mendudukan diri sebagai orang yang berpengaruh di Indonesia ternyata mengalami nasib pahit. Fenomena ini berpretensi buruk bagi generasi muda yang membutuhkan model keteladanan. $\mathrm{KH}$ Abdulah Gymnastiar (Aa Gym) menyebut kasus korupsi sebagai kasus krisis keteladanan dalam menjalankan sumpah jabatan. Betapa tidak, walaupun sudah disumpah - misal bagi yang beragama Islam disumpah dengan Al-Qur'an - ternyata tetap saja terjadi krisis keteladanan.

${ }^{8} \mathrm{Hal}$ ini seperti dimaksud oleh Shihab yang menyatakan bahwa di dalam Kitab suci Al-Qur'an terdapat dua kata yang dipergunakan untuk menunjuk makna kepemimpinan. Pertama, menggunakan istilah Khalifah, dan kedua memakai istilah imam (Kartakusumah, 2006:22)

9 Gambaran penari Sunda pada masa lampau memang seperti Enoch, dipastikan manjing 
atau masagi atau balans sebagai praktisi tari dan juga praktisi karawitan yang piawai.

10 Rd. Sukarna adalah Kepala Sekolah Sekolah Guru Bagian B (SGB), seorang menak yang piawai membuat dangding, yang tak lain merupakan ayah dari Tuti Sutiawati atau sekarang dikenal istri dari mantan Wakil Presiden RI, Try Sutrisno. Pada Gending Karesmen tersebut Tuti Sutiawati terlibat sebagai pemain, beserta teman sekolah di SGB yang lain, yakni Danasetia dan Koswara. Danasetia kelak menjadi Seniman dan Budayawan Jawa Barat, sedangkan Engkoswara menjadi Guru Besar di UPI dengan titel Profesor Doktor.

11 Dua karya terakhir yang ditelorkan Enoch secara pribadi bertujuan untuk memajukan dan mendukung minat sang anak, Asep Nugraha, untuk eksis pada bidang kacapi indung pada seni mamaos. Tidak heran jika sang anak yang biasa dilibatkan menari, pada dua karya terakhir Enoch ditempatkan sebagai penabuh kacapi indung.

${ }^{12}$ Tulisan ini tidak memuat bahasan secara keseluruhan buah pemikiran Enoch sebagai seniman pemikir, mengingat jumlah karya dari buah pemikirannya sangat banyak. Oleh karena itu penulis hanya membahas contoh kontribusi Enoch sebagai seniman pemikir dengan mengetengahkan karya yang dinilai monumental dan mewakili karya pemikiran lainnya.

13 Diberi nama Sayang Kalong karena rumah tersebut diibaratkan sarang kelelawar, menjadi aktif ketika malam hari dan pasif pada siang hari. Aktivitas yang ditangkap dari penghuni rumah itu laiknya aktifitas kelelawar yang ramai ketika malam hari.

${ }^{14}$ Para pemuda yang berkumpul di Sayang Kalong telah disebutkan Saini KM pada Koran Pikiran Rakyat. Para pemuda itu pada kemudian hari menjelma menjadi tokoh budayawan, seniman, dan Sastrawan Sunda yang mampu 'berbicara banyak' sebagai tokoh sentral pada kancah percaturan kaum intelektual Sunda.

15 Dianalogikan seperti kumpulan orang buta yang berdebat mengenai bentuk gajah itu seperti apa. Orang buta ke-1 yang kebetulan berada di depan memegang bagian belalai, menyimpulkan bahwa gajah itu sejenis binatang yang berbentuk seperti pipa elastis yang panjang dan mendenguskan udara. Orang buta ke-2 di samping Orang buta ke-1, mencoba membuktikan dengan memegangnya, namun bukan belalai yang terindentifikasi melainkan gading, lalu menyangkal keras pendapat orang buta ke-1, menyatakan:"Gajah itu binatang seperti pipa yang keras dan kaku, sama sekali tidak elatis apalagi bisa menghembuskan udara." Orang buta ke-3 mencoba mengidentifikasi bentuk gajah, kebetulan yang terpegang adalah telinga dan berkata: "kalian salah besar, gajah itu seperti lembaran daging yang lebar. Orang buta ke-4 yang berada di samping orang buta ke-3 mencoba membuktikan pernyataan orang buta ke-3, mendekati gajah dan menabrak bagian kaki gajah lalu merangkulnya: "apanya yang kaya pipa atau lembaran daging, gajah itu seperti batang pohon menjulang ke atas". Orang buta ke-5, yang dari tadi mendengarkan perdebatan teman-temannya penasaran dan maju ke depan memegang gajah pada bagian badannya lalu berteriak: "Gajah itu seperti bus dengan ukuran yang besar". Orang buta ke-6 yang kebetulan adalah pemimpin mereka dibuat bingung dengan perdebatan anak buah yang disuruh mendeskripsikan gajah di depan mereka. Ia maju ke depan dan memegang gajah: "Sontoloyo, bodoh semua, gajah itu binatang yang besarnya seperti tambang, mungkin sejenis ular!" (ia memegang bagian ekor gajah). Analogi pada cerita anekdot tersebut adalah gambaran prespektif orang perorang dalam mengidentifikasi permasalahan yang menjadi isu. Hasilnya bisa berbeda dan bisa pula sama, tergantung perspektif di mana ia memandang.

${ }^{16}$ Nama-nama Pemimpin Redaksi beserta anggotanya dikutip penulis dari Majalah Bulanan Haruman Pengemban Pancasila dan Pengabdi Ampera No 1, Tahun ke-1 (1966).

17 Kepiawaian Enoch membawakan presentasi sebagai buah pemikirannya yang kritis 
memikat Mantle Hood, Founding Father of Etnomusicology in the United States of America, yang menjabat sebagai Direktur Institute of Ethomusicology di University of California Los Angeles (UCLA), untuk memberikan grant dari JD Rockefeller $3^{\text {rd }}$ kepada Enoch menyelesaikan perkuliahan pada institusi yang dipimpin Hood selama tiga tahun.

18 Dedikasi Enoch mendirikan KORI Bandung menjadi dasar bagi Pemerintah Republik Indonesia melalui Keputusan Presiden (Kepres RI) Nomor 053/TK/Tahun 2003 untuk menganugrahkan penghargaan Satyalancana Kebudayaan kepada Enoch yang diberikan Presiden Megawati Soekarnoputri pada tanggal 12 Agustus 2003.

19 Kontribusi Enoch sebagai Penggagas, Pendiri, dan Pengajar pada FKSS IKIP Bandung seperti tersurat dalam Piagam Penghargaan yang diberikan UPI Bandung kepada Enoch Atmadibrata, bernomor 2456/H.40.3/DT/2007 pada tanggal 28 Desember 2007, ditandatangani oleh Dekan Fakultas Pendidikan Bahasa dan Seni, Prof. Dr. Hj. Nenden Sri Lengkanawati, M.Pd.

\section{DAFTAR PUSTAKA}

Atmadibrata, Enoch. 1996. "Enoch Atmadibrata dan Teater" manuskrip belum diterbitkan. 1999. Daya Mahasiswa Sunda Sirungan Deui: Sirungna Loba Bibit Unggul. Majalah Mangle. Bandung: Mangle. 2005 "Pak Karman Somawidjaya Dengan Kepeduliannya Terhadap Seni Sunda”, naskah Otobiografi belum diterbitkan.
Benny, Cornelia J. 2004. "Sekelumit Cerita Tentang Noch Atmadibrata dan Konservatori Tari: Kenangan untuk Noch Atmadibrata dari Murid-Murid, Rekan-Rekan, Sahabat, dan Kerabat." Bandung: Dies Natalis IX STSI Bandung, 29 Agustus.

Brinner, Benjamin. 1995. Knowing Music Making Music: Javanese Gamelan and Theory of Musica Competence and Interaction. Chicago \& Landon: The University of Chicago Press.

Gulo, W. 2005. Strategi Belajar-Mengajar. Jakarta: PT. Grasindo.

Kartakusumah, Berliana, 2006. Pemimpin Adiluhung Genealogi Kepemimpinan Kontemporer. Jakarta: PT Mizan Publika.

Kosim, Saini. 1984. "Cita-Cita yang Melatarbelakangi Sundanologi" dalam Harian Umum Pikiran Rakyat Bandung, tanggal 8 Juni 1984.

Nugraha, Asep. 2007. "Pemain Kacapi Indung Seni Tembang Sunda Cianjuran: Kajian Peraihan Derajat Kompetensi." Laporan Penelitian Beasiswa Unggulan. Bandung: STSI Bandung.

Risyani. 2008. "Inspirasi Kreatif Enoch Atmadibrata dalam Penataan Tari Cendrawasih." Jurnal Seni dan Budaya Panggung. Vol 18. No 2. April-Juni: 160-174. 
Rosidi, Ajip [ed]. 2000. Ensiklopedi Sunda: Alam, Manusia, dan Budaya Termasuk Budaya Cirebon dan Betawi. Jakarta: Pustaka Jaya.

Sudyarto, D.S. 1977. "Enoch Atmadibrata, Benih yang Tumbuh di Atas Tanah Tandus", Koran Kompas. Jakarta: Selasa, 20 September.

Sukanda. 1991. "Mengenal Bapak Ojo Tokoh Degung Purbasasaka".Dalam Buletin Kebudayaan Jawa Barat Kawit No 43. Bandung: Yayasan Kebudayaan Jayaloka.

Suratno, Nano. 1980 "Sabundeureun Karawitan Tari Sunda”. Bandung: Daya Mahasiswa Sunda Panitia Pasanggiri Tari Sunda Tingkat SLP-SLA Sa Jawa Barat.

Tilaar, H.A.R. 1998. Beberapa Agenda Reformasi Pendidikan Nasional Dalam Perspektif Abad 21. Magelang: Tera Indonesia.

\section{DAFTAR SINGKATAN}

Balita

BJ

C

CD

$\mathrm{Cm}$

DKI

DPL

G

ISBI

$\mathrm{M}$

MK

$\mathrm{N}$

Orba

Orla

PK

$\mathrm{PT}$

PR

$\mathrm{Rd}$

RI

TFA

VCD
Bayi di bawah Lima Tahun

Berat Jenis

Pancer

Compact Disc

Centi Meter

Daerah Khusus Ibukota

Dari Permukaan Laut

Goong

Institut Seni Budaya Indonesia

Meter

Mata Kuliah

Kenong

Orde Baru

Orde Lama

Paket Keahlian

Perguruan Tinggi

Pekerjaan Rumah

Raden

Republik Indonesia

Tenaga Fungsional Akademik

Video Compact Disc 